\title{
Socio-Spatial Inequality and Violence
}

\author{
Cecilia Hita Alonso, Leticia Sánchez Hita \\ The Sociology Department, University of Granada, Granada, Spain \\ Email: cehita@ugr.es
}

Received June 28 $8^{\text {th }}$, 2013; revised August $11^{\text {th }}, 2013$; accepted August $23^{\text {rd }}, 2013$

\begin{abstract}
Copyright (c) 2013 Cecilia Hita Alonso, Leticia Sánchez Hita. This is an open access article distributed under the Creative Commons Attribution License, which permits unrestricted use, distribution, and reproduction in any medium, provided the original work is properly cited.
\end{abstract}

\begin{abstract}
Since the 70s, neo-liberalism has lead to increased social segregation and the segmentation of land according to a population's social-economic status and the transformation of the labour market. That is to say, we are experiencing a process of social-spatial segregation which can be defined as the agglomeration of families with the same social condition in separate spaces. Segregation can depend on ethnicity, migration background or socio-economic situation, among other conditions and it impairs the mechanisms of social cohesion as it generates social differentiation which in turn breeds tension and fear. This mechanism is leading to the appearance of new areas such as gated communities, gentrification, hyper-degraded areas etc., which are as much a result of the heavy spatial concentration of the elite as of the agglomeration of the poor. This continues to happen, even with the knowledge that in the long-term, a non-segregated, inclusive space is one of several necessary measures in reducing violence and other dangerous behaviours, in the same way as a developed economy which fosters a stable and balanced job market. This article analyses the mechanisms which produce these processes.
\end{abstract}

Keywords: Socio-Spatial Segregation; Neo-Liberalism; Violence

\section{Introduction}

According to various studies, an increase in conflict and its most extreme manifestation-violence, both physical and real as well as symbolic or structural-has been detected in current societies. Furthermore, for the majority of individuals, this increase is due to certain social pathologies stemming from educational, instructive and family-related deficiencies; from the absence or change in the transmission of certain values. All of this has brought about the acceptance of violence as almost an innate part of "human nature", and as such, not eliminable in its entirety.

Without discussing if it has increased or not in our world (given that in the last instance, it would depend on the fact that what defines it as such is a determined society, immersed in the historical-social contextualisation of the concept), what is certain is that individualised behaviours are rarely related to social macro-structures, with the relationship between the two being avoided in analysis, separating them into two social dimensions ${ }^{1}$.

This article aims to establish this evaded relationship between current macro-structural tendencies and individual behaviours and vice versa, like a circular mechanism, structuring and structured, which is very evidently manifesting itself with the appearance of excluding (for specific population groups) and excluded (for other populations) spaces, which are bringing about a fractured, segmented and polarised social-spatial structure. These changes are a recipe for individual and collective violence, and lead us to question political attempts at solutions

${ }^{1}$ However, as Sennett (2003: p. 59) points out, "It may seem that all these issues are more subjective questions (...), but social forces shape these personal experiences in the same way that they shape more objective conditions". (whether legal, political, educative or ethical-moral) to decrease or control said violence.

\section{A Brief Exploration of the Concept of Violence in Today's Society}

Carrying out analyses and interpretations of conflict and violence and their relationships with processes of domination and social change plays a particularly important role in sociological theory; that is to say, the importance which domination (in its various forms) holds when these issues (conflict and violence) emerge.

\section{Violence in Classical Social Theory}

Given that Sociology emerges alongside modern society, we can establish some kind of relationship between modernity itself and the treatment of conflict and violence in scientific, medical and social sense, always with science as its base. From a scientific point of view, the supposed irrational or "animal" side to man would partly be its origin going through to the excess of rationality causing the great horrors of the 20th century. This has been demonstrated by Weber (1993) in his study of the State as an institution which holds the monopoly of the potential or actual use of violence. Furthermore, Bauman (2010) also agrees, as shown through the relationship he establishes between modernity and the holocaust. From a medical perspective, personality disorders or certain anatomical characteristics could help to identify those individuals more inclined to commit crimes or cause conflict. (Lombroso, 1976). From a social point of view, the social causes of violence would be studied and determined-marginalization, a lack of socialization, work-re- 
lated exploitation, arbitrariness in the use of power etc. Whatever the point of view, the interest would be the same- to acquire knowledge about the mechanisms which provoke violence, thus allowing us to stop it forever, but always within the prevailing order, the logic of the capitalist system and the legitimising, powerful discourse of those dominant.

\section{Violence in Contemporary Social Theory}

The crisis of modernity and the institutions which support it call into question the liberating impulse of rationality and the criteria of control and order that derive from it, as well as the mechanisms of analysis and intervention related to social imbalances. This does not mean declining to clarify the issue or attempting to avoid it, but instead, trying a change of perspective or approaching the issue from a different angle.

This new approach is due, amongst other factors, to the presence of mass media, the processes of cultural diffusion and the recognition of human rights in a great number of countries which have caused a social acknowledgement of the violence. Thus, the perception and generalisation of this issue has increased exponentially in the collective imaginary of our world. The appropriation of practices, expressions and social behaviours considered customary in previous societies have been emphatically and categorically reconfiguring themselves and branding themselves as violent.

For example, is smacking a child a way to teach them manners or is it a display of violence? Is the psychological, physical and economical submission of women in relation to men violence against women or a product of their "natural” inferiority? Are labour strikes a right of the workers or are they actions against the established order? These questions go some way towards displaying the evolution and the changes that are brought about from one era to the next-from an act of violence to a clearly recognised right; from a cultural standard or accepted custom to violence.

However, in a privatised and individualised world, the methods used to reduce or eradicate conflict are more particular and specific to the individual and his/her circumstances: mediation, psychological treatment or rehabilitation programmes. As a consequence, the permanence of structural violence, which is exercised by and within the system, goes unaddressed. Having reached this point, it is important to offer a suitable definition of violence within our social-historical context, distinguishing between certain terms which can be confusing in social discourse.

Aggressiveness and violence are not the same thing. The first is an instinct found in human beings (although not exclusively) which can act as a defence and protection mechanism for both the individual and the species; as such, it is natural. The latter, however, is social. It is learnt, channelled, strengthened or weakened according to culture and time period. It is directly related to processes of socialisation, integration and social adaptation. It does not exist in isolation but is relative and found within a social context; it is a singular phenomenon but manifests itself in many different ways ${ }^{2}$.

It emerges when personal achievements are much lower than the individuals' real potentialities due to reasons beyond their control, including the repressive, oppressive, limiting or excluding power of "social factors". As such, violence is woven into

\footnotetext{
${ }^{2}$ According to Galtung, "It is an act which consequently leads to the satisfaction of affective, physical and psychological necessities of the individual not being met due to another or other individuals".
}

the culture and the practice of this violence is aimed at shaping the control and power over of individuals or groups by others.

Echoing Galtung, for Habermas, this implies any mechanism of imposition over people or groups which make emancipation in the Kantian sense impossible; that is to say, the free choice of the individual. This means that our current definition is incredibly broad and detailed. To a large extent, we know when it is exercised over us, whether institutional, political, economical or due to age, gender, religion, ethnicity etc.

\section{The Relationship between the Macro-Structural Dimension and Daily Life in Terms of Area}

The changes made to the system of maximising the benefits of capitalism-defined as flexible, post-Fordist, global, informational or cognitive (Castell, 1999; Harvey, 2000; Giddens, 1990; Beck, 2000)—in line with postmodern cultural norms, "such as cultural logic of a late capitalism" (Jameson, 2001) and a legitimising neo-liberal discourse, are strengthening a movement of territorial modification which implies its own socio-spatial reconfiguration. Within this modification, we can also find a change of space-perception norms, creating collective imaginaries and with them, social and cultural practices. We are experiencing a deconstructing-reconstructing of spaceterritory, insofar as it is linked to the new model of production-circulation-consumption in a social context arranged around the general dimension of power of capital and with its efficiency and profitability in the territorial organisation, thus generating a strong imbalance between public and private, a dialectic process in which underlies the beginning of diffused and extended rivalry and legitimacy from micro to macro and vice versa (Workers, cities and regions: competent or incompetent).

Thus, new strategic spaces emerge and/or an abandonment or marginalisation of others occurs; we see unstable and volatile scenarios and territories, such as work or identity (Bauman, 2003). As such, area and changing situations complicate social and territorial organisation, governance, planning and management.

The economic system has injected a worldview into fields and establishments in order to monitor daily life, to paint our understanding of the world on our land and to stratify populations which move around within cities with very defined socioeconomic parameters, according to power gained by the families living there. As such, an omnipresent macro-structure takes control, ejecting or inviting individuals and families to conquer marginalised or forgotten spaces or areas hailed as the best and most expensive to live in, with corresponding security, order and care. In other words, the axis which organises land and distributes different areas according to power gained, is the difference between the actual price and that which is generated by the collective imaginary, calmed by the governing order in cities and areas where it isn't lived or exchanged; it just is. Where there are no social relationships or commercial exchanges, we only find a way of existing in the world, a habitus (Bourdieu, 1994), a life dedicated to forming links with a bourgeois and powerful class; the dominant class.

Within these mechanisms of escape and attraction of the population with relation to social class is hidden the segregation and the rupturing of a previously bonded society, or at least, one which was more participative in communal life and local daily happenings. This has given way to distrust, insecurity, fear and a lack of empathy which establishments have consid- 
ered necessary for the maintenance of the status quo and to legitimize security forces and armies. In reality, the feeling of general insecurity is more a climax created by the authorities in certain populations than a problem in itself. Thus, on the one hand the demand of the powerful classes to create separate, closed area for recreation and living is met, forming gated communities; on the other hand, the marginalization of the excluded community is maintained, with the problem continuing due to the two situations feeding off each other.

That is to say, the urban policies and the management of land, monitored by politicians with the decision-making powers, always favour the upper classes, even going beyond the demand, thus negatively affecting marginalised neighbourhoods, establishing an even greater difference between the populations and without any chance of climbing the social ladder. However, how is this process of social segregation brought about?

The current organization of productive processes on a global level is defined by two fundamental cores: the first, its uniform and homogenous character throughout virtually the whole planet, under the proposals of the neo-liberal paradigm. The second, the reorganization of territory (which in turn means a sociospatial reorganization) which simultaneously causes and necessitates the whole process ${ }^{3}$.

This was made evident during the seventies and the eighties with the consequent introduction of transversal processes such as the internationalisation of movements of capital, services, businesses, work and workers on a global scale. In the field we are dealing with, the relocation of businesses, subcontractors and the emergence of "maquila" or free zones, that is to say those areas which are subject to special by-laws related to work, syndication, taxes etc. should be highlighted. Moreover, the new organisation opts fundamentally for product diversification, flexible technology, qualified workers alongside those with hardly any qualifications; individualised work contracts; functional, temporal, wage-related and territorial mobility for workers; irregular, part-time, temporary and fragmented work schedules.

This entire process has relied on a tool as indispensable as it is inseparable in the meeting of objectives - the technological revolution of the seventies which now allows for rapid and easy exchanges of information, management, adaptation and communication in all current-day productive processes.

The consequence of all this is that both the relationship of the worker with his/her work and the relationships between workers themselves have undergone a significant change, marked by uncertainty, uprooting and the impossibility of a social and life plan, essential for generating identity, security and well-being in individuals Sennett (2010). It is marked by competitiveness, individualism and a lack of solidarity (Bauman, 2010; Beck, 2010; Sassen, 1991).

The most evident manifestation of this change is the progressive increase in social differentiation in various collectives, the social-spatial fragmentation and even, for many authors, the imminent danger of an increase in social polarisation; a world

\footnotetext{
${ }^{3}$ As Harvey shows us, "Capitalism constructs and reconstructs a geography according to its own image. It creates a specific geographic landscape, a space which is the product of transport and connections, of infrastructure and territorial organizations which facilitate the accumulation of capital during a period of its history which has to be broken down and reconstructed in order to pave the way for more amassing at a later stage. As such, if the word 'globalisation' means something concerning our recent geographic history, it is very probable that it is a new stage of this very process which underlies the capitalist production of the space” (2000: p. 72).
}

travelling at different speeds, splitting up into smaller and smaller pieces, bringing with it situations of conflict or violence.

This whole productive transformation cannot occur without changes being made to the space, from both a morphological and a social point of view. Below, we discuss how the space is changing and with what results.

\section{The New Space}

According to the vast majority of researchers in the sociospatial field, (Harvey, 2010; Castells, 1999; Sassen, 1991; Jameson, 2001; Donzelot, 1999; Ascher, 2004; Davis, 2007), the reorganisation of productive processes goes hand in hand with the emergence of new spatial forms, in the same way that Fordist models, now virtually obsolete, generated a metropolitan model: central municipality and municipalities dependent on a vertically-organised hierarchy. The new spatial model does not adapt so much to a standard "type" but to a diversification, fragmentation and spatial differentiation corresponding to different social collectives. As such, what is truly interesting is the discovery of an "archipelagisation" of space to, on the one hand, embrace, and on the other, to separate various collectives according to socio-economic status, ethnicity, cultural norms etc.

Therefore, from a macro perspective, and to accommodate the management of global trade patterns, the global city is defined. (Sassen, 1991), which on the one hand amasses a large amount of "power", and on the other, has a strong potential for conflict, given that a large number of highly-qualified workers (necessary for management-based tasks and the running of tertiary activities) builds up along with a large number of workers with hardly any qualifications (necessary for "low-level knowledge” tasks). Thus is fed a large migrant collective with minimal levels of protection; they are likely to be exploited and furthermore, have very little possibility of climbing the social ladder. For this reason, to a large extent, "urban micro-struggles" play a prominent role, something we have been witness to over the past few decades (Los Angeles, in France-which started with Banlieue - in England etc.). Together with this collective, young people, those who have been marginalised or cast out, feed this potential for conflict even more, given that with conditions in the current job market and the failure of the state to act as a balancing force, their future suggests uncertainty and a lack of hope ${ }^{4}$.

Together with this dynamic, neo-liberal policies aim to improve conditions in order to reinforce private capital, the main focus in urban transformations. In turn, this leads to greater freedom for businesses and families in terms of realising locational preferences, making their strategies, decisions, and actions play an even more important role in the population's image, morphology and operational changes. This aids metropolistan expansion and the consolidation of a diversified social space, with specific skill levels ${ }^{5}$.

The following diagram displays a simplified idea of the rela-

\footnotetext{
${ }^{4}$ In the words of Perulli: "Over these years, significant social modifications have expanded the field in a 'downwards' manner. More selective individual strategies with regard to work and dwelling, more freedom in terms of labour supply and a greater diversification of work time-spaces have had effects on many layers of the urban population in the last few years. This has caused social erosions-working class and manufacturing employeeswhere previously in this area, behaviours were more stable and predictable. The 'upward' fragmentation (new tertiaries) and the downward (infraclass) of the metropolitan job market has subsequently caused the connective urban tissue to fray" (1995: p. 47).
} 
tionships we have established (Figure 1).

Using these axes, we can place both the causes and consequences of violence. In reality, we have argued that the causation related to the city and violence is far from being a onesided relationship, and as such we cannot discuss any single, one causal origin. On the contrary, it is a process which, being social in its nature, comes about due to various phenomena and the results of these developments produce either more conflict within a population or, with luck, lessen it. In other words, the structural and economic violence found in the domination and exploitation of late capitalism generates violence within a territory; land which is organised at the mercy of this capitalism and which feeds off the dialectic process, nourished by individualism and social segregation.

The different types of spaces which are products of this dynamic are reflected in the table below (See Table 1).

All of these spaces become "stagnant compartments", excluding and excluded, with various levels of security and with a common denominator-a growing fear, a permanent state of alert when faced with other groups not acknowledged as their own, whether socially or spatially ${ }^{6}$.

As such, the processes by which socio-territorial segregation is produced have two aspects which are worth considering. Firstly, the downgraded space, inhabited by those who have been excluded, is in a state of permanent closure, and generates a lack of mobility, of which the inhabitants are clearly aware of, thus producing an identity differentiating them from the upper classes, which is made evident in the behaviour of the population living in these disadvantaged zones. This creates an intimidation and a lack of apathy for and within their land, with no other way out but for conflict.

Secondly, the fragmentation of a city which is determined by inequality whilst simultaneously feeding it, creates a real and symbolic border within itself, which on the one hand protects and on the other, excludes. It creates an additional "other" out of the municipalities which are officially defined and treats this other as a "foreigner". The movement of foreigners, who are simply individuals with a different acquired level and consequently belonging to a different social class, provokes, intimidates, invades and incites those living in that area, and only turns their entrance into a potential threat to communal life and social relationships. It is essential to introduce neo-liberal mechanisms because as well as organizing the territory and segregating it, they also privatise the use of urban land and define areas as temporary rather than establishing zones for exchange and collectivisation. This individualisation is separating civilians from others and symbolically pressuring them to acquire protection and security against "the foreigner". Thus, the feeling of insecurity invokes and produces fear in any street scene; a spiral response to a fictitious insecurity is produced, and ends up turning into real violence.

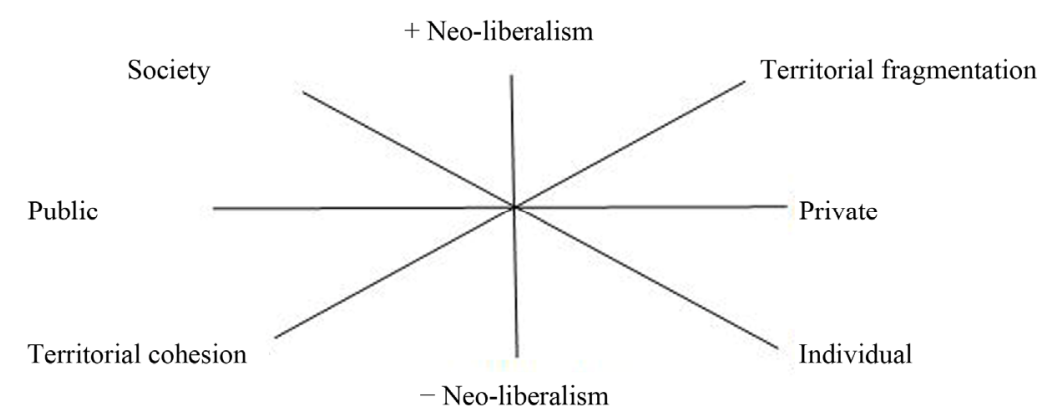

Source: Own work. Axes involved in the rupturing of social tissue (related to the increase in the perception and manifestations of violence)

Figure 1.

Territorial and process economic relationships.

Table 1.

Table types of spaces.

\begin{tabular}{cccccccc}
\hline Denomination & Location & $\begin{array}{c}\text { Socio-economic } \\
\text { profile }\end{array}$ & $\begin{array}{c}\text { Level of socio-spatial } \\
\text { mobility }\end{array}$ & $\begin{array}{c}\text { Level of } \\
\text { education }\end{array}$ & $\begin{array}{c}\text { Level of the } \\
\text { notion of security }\end{array}$ & $\begin{array}{c}\text { True } \\
\text { violence }\end{array}$ \\
\hline Elite neighbourhoods & Central spaces of metropolitan areas & High & Very high & High & High & Low \\
Peripheral neighbourhoods & $\begin{array}{c}\text { Peripheral zones of cities or central, } \\
\text { degraded neighbourhoods }\end{array}$ & Low & Low & Low & Low & High \\
Gated communities & $\begin{array}{c}\text { Peripheral zones, away from the city } \\
\text { Alongside developing cities in } \\
\text { under-developed countries }\end{array}$ & Very high & Very low & Very high & Very high & Very high & Non-existent \\
Hyper-degraded areas & \begin{tabular}{c} 
Nont \\
\hline
\end{tabular} & & None & N/A & No data \\
\hline
\end{tabular}

Source: Own work.

\footnotetext{
${ }^{5}$ The neo-liberal city is the image of globalisation, of which it is both the privileged base and the final outcome. After extreme polarisation, it has been reproduced on its own scale, projected and imprinted on the space, the increasing imbalances and contradictions bred by 250 years of liberal reforms and cut-throat competition. All around us, the tendency for a growing number of people to live informally and in unstable conditions, has increased and worsened (Delcourt, 2008: p. 31).

${ }^{6}$ In relation to this, Davis states, "my re-reading of the urban structure map (...) maintains ecological factors such as income, land value, class and race but adds in a new and decisive factor: fear" (2001: p. 7).
} 
Here we should explain how the majority of political, and consequently urban, decisions succumb to our economic model; a model which privatizes space, distributes land unequally and functionally, and is deeply affected by work relationships. Furthermore, it is the instigator of a different style of daily life depending on the purchasing power and social strata of the specific neighbourhood population. As such, the probability of conflict being produced varies depending on what the city and each neighbourhood within it symbolizes for the inhabitants and the others, for economic prospects and for work relationships and it particularly depends on political will.

In this way, urban management and public policies are able to respond to social demand and cohesion or to segregation, which creates an ideal breeding ground for a complete lack of understanding. The dependence on a strict nucleus makes the remaining departments subrogated and dependent on a territory in which a high concentration of businesses end up; a territory which is capable of capturing the attention of urban politics and the best aesthetics which increase land value and break up the city even further. The result is clear-a poorly-lit neighbourhood, with no social or economic activity, distanced from the centre, as such serving as a social landscape for wrong-doers and thieves, continually feeding the problem, generating on the one hand more violence, and on the other, a space for further criminal activities. These places tend to be forgotten and abandoned by urban policies, which prefer to intervene in areas which are already acknowledged as prosperous, where the poor image of beggars or prostitutes is sidelined. We shouldn't forget that criminality is a behaviour acquired in the processes of socialisation and trade, in which roles are quickly and rashly determined for those offenders in surrounding areas. We can confirm that in the same way that an unbalanced territorial organisation generates violence, the different types of violence reinforce a fragmented territory.

In the following conceptual model, we have attempted to establish these relationships, departing from the current economic model in order to explore new territorial models as mutuallyfeeding processes (Figure 2).

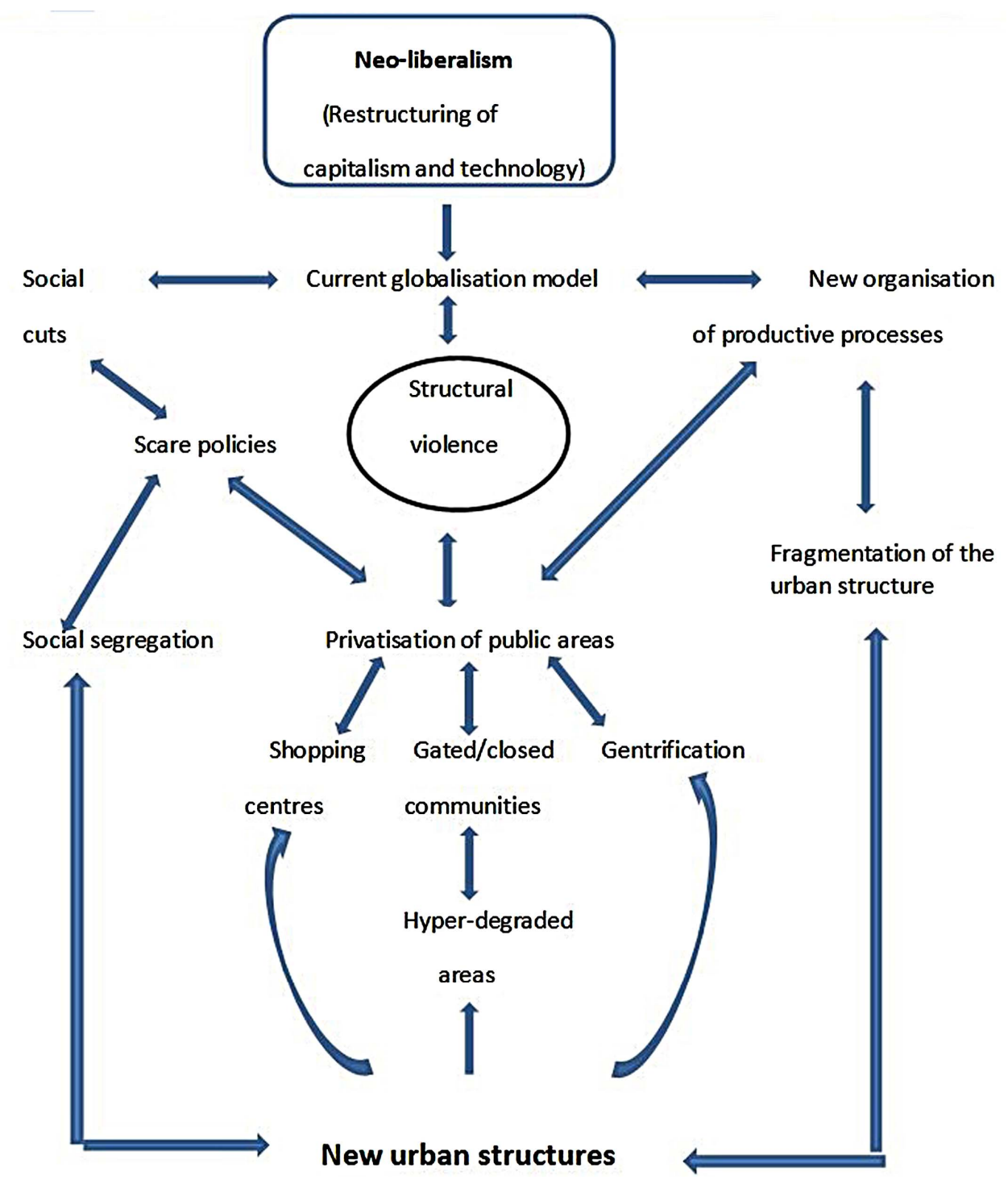

Figure 2.

Conceptual model of current economic process. 


\section{Conclusion}

The current territorial organisation and management, inseparable from the organisation of productive processes and the job market, amasses a series of "risk factors" for the emergence and/or the strengthening of conflict as a doorway to violence. As such, although social acknowledgment of violence has increased, the necessary structural changes to control this destructive process have not been carried out. This does not mean, per se, that spaces generate violence, but that specific social conditions (cultural, economic, political and spatial) constitute an excellent breeding ground for it. This entails a change in social relationships, making them competitive, individualist, suspicious etc., thus continuing the cycle.

On the other hand, every kind of violence is particularly evident in cities and adjoining spaces. These areas multiply its effect due to the attention they bring and, subsequently, the social repercussions are greater in highly populated areas.

At the same time, processes which legitimise and encourage violence are having effects on managed territories, following the principles of economic development, social isolation, unstable working conditions and the control of order and authority by the governments and dominating forces.

If we concentrate more on violent outbreaks which have occurred in urban spaces, many of which have spread to other cities-France, England, Greece, Spain, Chile, the USA, etc., we can see the symptoms of the rejection of an economic, political, environmental, cultural and symbolic structural violence which, unfortunately, are immersed in strong complimentary synergies.

Whatever the case, it is evident that acknowledging violence does not necessarily lead to its elimination. In fact, it remains extraordinarily alive. Maybe reporting of social macro-structural tendencies is not strong enough. Indeed, if these social axes are origin of conflict, it would mean a large-scale socio-economic convulsion which a large part of the population is not willing to take on.

\section{REFERENCES}

Ascher, F. (2004). Los nuevos principios del urbanismo: El fin de las ciudades no está a la orden del día. Madrid: Alianza.

Bauman, Z. (2003). Modernidad líquida. México: Fondo de Cultura Económica.

Bauman, Z. (2010). Modernidad y holocausto. Madrid: Sequitur.

Bourdieu, P. (1994). Razones prácticas. Barcelona: Anagrama

Beck, U. (2000). Un nuevo mundo feliz: La precariedad del trabajo en la era de la globalización. Barcelona: Paidós Ibérica.

Castells, M. (1999). La era de la información: Economía sociedad y cultura. La sociedad red. Madrid: Alianza.

Davis, M. (2001). Control urbano: La ecología del miedo. Bilbao: Luna.

Davis, M. (2007). El planeta de las ciudades miseria. Madrid: Verso.

Delcourt et al. (2008). Explosión urbana y globalización. Madrid: Popular.

Donzelot, J. (1999). La nouvelle question urbaine. Paris: Revue Esprit.

Giddens, A. (1990). Consecuencias de la modernidad. Madrid: Alianza. Harvey, D. (2000). Espacios de esperanza. Madrid: Akal.

Jameson, F. (2001). Teoría de la postmodernidad. Madrid: Trotta.

Lombroso, C. (1876). L'Uomo delinquent. Torino: Bocca.

Perulli, P. (1995). Altas metropolitano. El cambio social en las grandes ciudades. Madrid: Alianza.

Sennett, R. (2010). La corrosión del carácter, las consecuencias personales del trabajo en el nuevo capitalismo. Barcelona: Anagrama.

Sennett, R. (2003). El respeto: Sobre la dignidad d el hombre en un mundo de desigualdad. Barcelona: Anagrama.

Sassen, S. (1991). The global city. New York, London, Tokyo. Princeton: Princeton University Press.

Weber, M. (1993). Economía y sociedad. Esbozo de sociología comprensiva. Madrid: Fondo de Cultura Económica. 